\title{
New methods and technologies for enhancing usability and accessibility of educational data
}

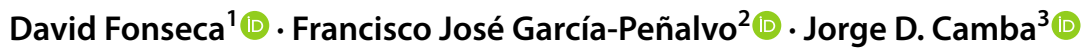

Published online: 26 October 2020

c) Springer-Verlag GmbH Germany, part of Springer Nature 2020

Recent advances in information and communication technologies (ICTs) have fostered the development of new methods and tools for exploring the increasingly large amounts of data that come from pedagogical domains [1-5]. These data have the potential to transform education into a personalized experience $[6,7]$ that meets the needs of each individual student [8]. Educational data research is becoming highly relevant in massive online courses [9], especially MOOCs (Massive Open Online Courses) [10-13] and SPOCs (Small Private Online Courses) [14-16]. Educational data are also the basis for learning analytics [17-19], with an increasing focus on the way educational data are presented [20-22], how users interact with the data [23-26], and data privacy and security [27-30].

There are many types of data that can support student's learning [31], but the type and nature of the data, how they can be accessed, and who can access them, vary significantly. Whether educational data are collected from collaborative learning environments [32-34], course management systems [35, 36], gamified training applications [37, 38], or administrative systems from schools and universities [39-41], valuable properties, patterns, and insights often emerge. When combined with other factors such as timing and context, these factors play an important role in understanding how students learn [42], the settings in

Francisco José García-Peñalvo

fgarcia@usal.es

David Fonseca

fonsi@salle.url.edu

Jorge D. Camba

jdorribo@purdue.edu

1 La Salle, Ramon Llull University, Sant Joan de la Salle 42, 08022 Barcelona, Spain

2 Computer Science Department, Plaza de los Caídos s/n, 37008 Salamanca, Spain

3 Department of Computer Graphics Technology, Purdue University, West Lafayette, IN, USA which they learn [43], and the effectiveness of the educational approaches [44]. Extracting information from data to ultimately turn it into knowledge $[45,46]$ can contribute to draw a more comprehensive picture of student's learning, which can empower students, parents, and educators as well as education stakeholders and policymakers [47].

Educational data usability and accessibility is even more relevant in the context of the global pandemic due to the SARS-CoV-2 virus, which causes COVID-19 disease. This situation is having an unprecedented impact on education. According to UNESCO [48], in the first months of 2020, the pandemic has affected $91.3 \%$ of the total number of students enrolled worldwide: over 1.5 billion people have been unable to receive face-to-face instruction because of the closure of schools and universities [49]. The consequences are more severe in emerging countries $[50,51]$ and to families affected by poverty and risk exclusion [52], presenting digital inequalities [53], and causing exclusion and inequality situations in vulnerable groups, ethnic minorities, and people with disabilities [54]. Significant challenges have been reported in the online transformation of educational activities [55, 56], particularly assessment processes [57].

Consequently, it is vital to improve access to educational technologies and reduce gaps in use and literacy [58]. A multi-disciplinary approach is required to deploy technological ecosystems $[59,60]$ that favor blended or online training, teacher and student training for the efficient use of educational technologies [61], and policies for both government and academic leaders to define strategies and manage uncertain scenarios [62]. In the context of educational data access, it is critical to ensure transparency, ethics, and individuals' rights.

This UAIS special issue builds on the work started in a number of previous special issues [63-66] and two international events:

- The invited session entitled "Emerging interactive systems for education", in the thematic area "Learning and 
Collaboration Technologies", in the context of the 21 st HCI International Conference 2019, in Orlando, USA, with 25 papers accepted $[67,68]$.

- The organization of the 7th Edition of Technological Ecosystems for Enhancing Multiculturality, in León (Spain), with more than 200 presentations [69].

This special issue focuses on how to improve universal access to educational data, with emphasis on (a) new technologies and associated data in educational contexts: artificial intelligence systems [70], robotics [71-73], augmented [74-76] and virtual reality (VR) [77-81], and educational data integration and management [82]; (b) the role of data in the digital transformation and future of higher education: Personal Learning Environments (PLE) [83, 84], mobile PLE [85, 86], stealth assessment [87], technology-supported collaboration and teamwork in educational environments [88], and student's engagement and interactions [89, 90]; (c) user and case studies on ICTs in education [91, 92]; (d) educational data in serious games and gamification: gamification design [93-96], serious game mechanics for education [97, 98], ubiquitous/pervasive gaming [99], and game-based learning and teaching programming [100, 101]; and (e) educational data visualization and data mining [102]: learning analytics [103], knowledge discovery [104], user experience [105, 106], social impact [107], good practices [108], and accessibility $[109,110]$.

The special issue comprises the following 11 accepted papers.

Collaborative learning systems are a niche for analyzing educational data. For example, virtual reality and 3D modeling applications can leverage the integration of collaborative approaches in Medicine [111], Architecture [112], or Urbanism [113]. Huang et al. developed a study devoted to construct a 3D modeling practice field based on virtual reality technology, in which students can learn 3D modeling through a new VR design collaboration framework and complete design goals. The proposed design collaboration model includes the concept of a learning community. The results of this study indicate that the system usability of the VR modeling practice field is superior to that of the traditional modeling learning field and learners are more creative and motivated. The authors emphasize that through the new design collaboration model, students can effectively learn 3D modeling in VR. Conde et al. explore the assessment of instant messaging tools for the acquisition of teamwork competence throughout a case study about the use of the instant messaging app WhatsApp. From the results, the authors conclude that students prefer instant messaging tools in teamwork activities over other interaction tools such as forums; and that the use of those tools has a positive impact on students' grades.
In an effort to demonstrate the potential of virtual worlds in education [114], especially in distance education [115], Krassmann et al. introduce a framework to prepare the implementation of virtual worlds. Their approach emphasizes requirements that distance education students need to meet in order to have a successful learning experience. The authors present an exploratory study and propose eight guidelines to harness the potential of the technology of virtual worlds for distance education.

Pervasive games [116] enhance the gaming experience and level of engagement by including real world aspects into the game space. Arango-López et al. propose GeoPGD, a methodology that integrates the design of geolocated narrative as the core of the game experience. This methodology guides designers and developers through the different stages of building a pervasive game by providing tools for defining the narrative components, places, and interactions between the user and the game.

Gallego-Durán et al. tackle the challenges of learning programming as a universal ability [117, 118]. The authors propose a radically different perspective to this issue, teaching students with a bottom-up approach, starting from machine code and assembly programming. Their results suggest that such a small intervention could have a limited positive influence on the students' programming skills.

Pazmiño et al. did a systematic literature review [119] to answer the question: What is the baseline of scientific documents on learning analytics in Ecuador? The selected documents were analyzed using Statistical Implicative Analysis after removing duplicates and applying inclusion, exclusion, and quality criteria. The outcome of this research has allowed building up a baseline of scientific knowledge about learning analytics in Ecuador.

User experience analysis in the educational realm is directly linked to the levels of user acceptance and satisfaction [120] of the new wave of educational technological ecosystems and the personalization of learning [121]. Barneche-Naya and Hernández-Ibañez describe the results of a case study intended to compare three different user movement paradigms (metaphoric, symbolic and natural) designed to control the visit to virtual environments for a NUI-based museum installation. The study evaluates the performance of each movement scheme with respect to the navigation of the environment, the degree of intuitiveness perceived by the users, and the overall user experience. The results show that the natural movement scheme stands out as the most adequate for the contemplation of the virtual environment and the most balanced at a general level for the three variables considered. The symbolic scheme proved to be the most efficient. The natural movement and symbolic schemes appear to be the most appropriate to navigate digital environments such as museum installations. In another paper related to user experience, Zardari et al. introduce an 
e-learning portal for higher education that was assessed from a user experience standpoint using an eye-tracking system. The results emphasize students' satisfaction with the learning portal. Finally, Toborda et al. analyze metrics to measure effectiveness and engagement levels in pervasive gaming experiences.

Regarding the analytics of accessibility, Martins et al. present a study that assesses accessibility in mobile applications, which may be applicable to education and tourism [122]. Fourteen mobile applications were analyzed using a manual and automatic methodology through an evaluation model based on quantitative and qualitative requirements, as well as the use of features such as VoiceOver and TalkBack. The results show a high number of errors in most quantitative requirements as well as non-compliance with most qualitative requirements. Also, in the context of accessibility, Romero Yesa et al. share a good practice in designing accessible educational resources [123]. The authors developed a new virtual teaching unit for supporting classroom teaching based on usability and accessibility criteria. The goal is to help increase teaching quality by improving syllabus design.

Acknowledgements The guest editors would like to thank the Universal Access in the Information Society journal Editors-on-Chief, Dr. Constantine Stephanidis and Dr. Margherita Antona, for their confidence in our responsibility to lead this special issue. We want to express our gratitude to all the researchers that have made this special issue a reality. This work was partially funded by the Spanish Government Ministry of Economy and Competitiveness throughout the DEFINES project (Ref. TIN2016-80172-R).

\section{References}

1. Chen G, Yang J, Hauff C, Houben G-J LearningQ: A Large-scale Dataset for Educational Question Generation. In: Procedings of the Twelfth International AAAI Conference on Web and Social Media, ICWSM 2018 (June 25-28, 2018 in Palo Alto, California, USA). Association for the Advancement of Artificial Intelligence (AAAI), Palo Alto, California, USA, 481-490 (2018)

2. Villagrá-Arnedo, C.J., Gallego-Durán, F.J., Llorens-Largo, F., Satorre-Cuerda, R., Compañ-Rosique, P., Molina-Carmona, R.: Time-dependent performance prediction system for early insight in learning trends. International J. Interact. Multimed. Artif. Intell 6(2), 112-124 (2020). https://doi.org/10.9781/ijima i.2020.05.006

3. Le, A.-V., Do, D.-L., Pham, D.-Q., Hoang, P.-H., Duong, T.-H., Nguyen, H.-N., Vuong, T.-T., Nguyen, H.-K.T., Ho, M.-T., La, V.-P., Vuong, Q.-H.: Exploration of youth's digital competencies: A dataset in the educational context of vietnam. Data 4(2), 69 (2019). https://doi.org/10.3390/data4020069

4. Gomes, C.M.A., Jelihovschi, E.: Presenting the regression tree method and its application in a large-scale educational dataset. International J. Res. Method Educ. 43(2), 201-221 (2020). https ://doi.org/10.1080/1743727X.2019.1654992

5. Kantor A, Rafaeli S Open PISA: Dashboard for Large Educational Dataset. In: Proceedings of the Seventh ACM Conference on Learning @ Scale, L@S '20 (Virtual Event USA
August, 2020). ACM, New York, NY, USA, pp 253-256. (2020) doi:https://doi.org/10.1145/3386527.3406721

6. Zhang, L., Basham, J.D., Yang, S.: Understanding the implementation of personalized learning: A research synthesis. Educ. Res. Rev. 31, 100339 (2020). https://doi.org/10.1016/j. edurev.2020.100339

7. Walkington, C., Bernacki, M.L.: Appraising research on personalized learning: Definitions, theoretical alignment, advancements, and future directions. J. Res. Technol. Educ. 52(3), 235-252 (2020). https://doi.org/10.1080/15391 523.2020.1747757

8. Berlanga, A.J., García-Peñalvo, F.J., Sloep, P.B.: Towards eLearning 20 university. Interact. Learn. Environ. 18(3), 199201 (2010). https://doi.org/10.1080/10494820.2010.500498

9. García-Peñalvo, F.J.: La sociedad del conocimiento y sus implicaciones en la formación universitaria docente. In: Toledo Lara, G. (ed.) Políticas, Universidad e Innovación: Retos y perspectivas, pp. 133-155. Bosch, Barcelona, España (2020a)

10. García-Peñalvo, F.J., Fidalgo-Blanco, Á., Sein-Echaluce, M.L.: An adaptive hybrid MOOC model: Disrupting the MOOC concept in higher education. Telemat. Inform. 35, 1018-1030 (2018). https://doi.org/10.1016/j.tele.2017.09.012

11. Lerís, D., Sein-Echaluce, M.L., Hernández, M., Fidalgo-Blanco, Á.: Participantes heterogéneos en MOOCs y sus necesidades de aprendizaje adaptativo. Educ. Knowl. Soc. 17(4), 91-109 (2016). https://doi.org/10.14201/eks201617491109

12. Hernández, B., de Galindo, M.J., Ramírez-Montoya, M.S.: Innovation in the instructional design of open mass courses (MOOCs) to develop entrepreneurship competencies in energy sustainability. Educ. Knowl. Soc. 20, 5 (2019). https://doi.org/10.14201/ eks2019_20_a5

13. Ortega-Sánchez, D., Gómez-Trigueros, I.M.: Massive open online courses in the initial training of social science teachers: Experiences, methodological conceptions, and technological use for sustainable development. Sustainability 11(3), 578 (2019). https://doi.org/10.3390/su11030578

14. Belarbi, N., Chafiq, N., Talbi, M., Namir, A., Benlahmar, H.: A recommender system for videos suggestion in a SPOC: A proposed personalized learning method. In: Farhaoui, Y., Moussaid, L. (eds.) Big Data and Smart Digital Environment, pp. 92-101. Springer International Publishing, Cham, Switzerland (2019)

15. Zhou J, Yu H, Chen B, Mai C, Yu L The construction of teaching interaction platform and teaching practice based on SPOC mode. In: Proceedings of the 2016 11th International Conference on Computer Science \& Education (ICCSE'16) (Nagoya, Japan, 23-25 Aug. 2016). IEEE, USA, pp 293-298. (2016) doi:https:// doi.org/10.1109/ICCSE.2016.7581596

16. Shuying C, Lei C Exploration and Practice of SPOC Mixed Teaching Mode in Data Structure Course. In: Proceedings of the 4th International Conference on Modern Management, Education Technology and Social Science (MMETSS 2019) (Dalian, China, September 20-22, 2019). Atlantis Press, Amsterdam, The Netherlands, pp 397-400. (2019) doi:https://doi.org/10.2991/mmets s-19.2019.78

17. García-Peñalvo, F.J.: Learning analytics as a breakthrough in educational improvement. In: Burgos, D. (ed.) Radical Solutions and Learning Analytics: Personalised Learning and Teaching Through Big Data, pp. 1-15. Lecture Notes in Educational Technology, Springer Singapore, Singapore (2020b)

18. Conde MÁ, García-Peñalvo FJ, Fidalgo-Blanco Á, Sein-Echaluce ML Can We Apply Learning Analytics Tools in Challenge Based Learning Contexts? In: Zaphiris P, Ioannou A (eds) Learning and Collaboration Technologies. Technology in Education. 4th International Conference, LCT 2017. Held as Part of HCI International 2017, Vancouver, BC, Canada, July 9-14, 2017. Proceedings, Part II. Lecture Notes in Computer Science, vol 10296. 
Springer International Publishing, Switzerland, pp 242-256. (2017) doi:https://doi.org/10.1007/978-3-319-58515-4_19

19. Siemens, G.: Learning analytics the emergence of a discipline. America. Behav. Sci. 57(10), 1380-1400 (2013). https://doi. org/10.1177/0002764213498851

20. Verbert, K., Duval, E., Klerkx, J., Govaerts, S., Santos, J.L.: Learning analytics dashboard applications. Am. Behav. Sci. 57, 1500-1509 (2013)

21. Vázquez-Ingelmo, A., García-Peñalvo, F.J., Therón, R., Conde, M.Á.: Representing data visualization goals and tasks through meta-modeling to tailor information dashboards. Appl. Sci. 10(7), 2306 (2020). https://doi.org/10.3390/app10072306

22. Vázquez-Ingelmo, A., García-Peñalvo, F.J., Therón, R., AmoFilvà, D., Fonseca-Escudero, D.: Connecting domain-specific features to source code: Towards the automatization of dashboard generation. Clust. Comput. J. Networks, Software Tool Appl. In Press. (2020). https://doi.org/10.1007/s10586-019-03012-1

23. Gómez-Aguilar, D.A., Hernández-García, Á., García-Peñalvo, F.J., Therón, R.: Tap into visual analysis of customization of grouping of activities in eLearning. Comput. Hum. Behav. 47, 60-67 (2015). https://doi.org/10.1016/j.chb.2014.11.001

24. Álvarez-Arana, A., Villamañe-Gironés, M., Larrañaga-Olagaray, M.: Mejora de los procesos de evaluación mediante analítica visual del aprendizaje. Educ. Knowl. Soc. 21, 9 (2020). https:// doi.org/10.14201/eks.21554

25. Vieira, C., Parsons, P., Byrd, V.: Visual learning analytics of educational data: A systematic literature review and research agenda. Comput. Educ. 122, 119-135 (2018). https://doi.org/10.1016/j. compedu.2018.03.018

26. Noroozi, O., Alikhani, I., Järvelä, S., Kirschner, P.A., Juuso, I., Seppänen, T.: Multimodal data to design visual learning analytics for understanding regulation of learning. Comput. Hum. Behav. 100, 298-304 (2019). https://doi.org/10.1016/j.chb.2018.12.019

27. Amo, D., Alier, M., García-Peñalvo, F.J., Fonseca, D., Casañ, M.J.: Protected users: A moodle plugin to improve confidentiality and privacy support through user aliases. Sustainability 12(6), 2548 (2020). https://doi.org/10.3390/su12062548

28. Amo-Filvà, D., Alier, M., García-Peñalvo, F.J., Fonseca, D., Casañ, M.J.: Privacidad, seguridad y legalidad en soluciones educativas basadas en Blockchain: Una revisión sistemática de la literatura. RIED Rev. Iberoam. a de Educación a Distancia 23(2), 213-236 (2020). https://doi.org/10.5944/ried.23.2.26388

29. Ifenthaler, D., Tracey, M.W.: Exploring the relationship of ethics and privacy in learning analytics and design: Implications for the field of educational technology. Educ. Tech. Res. Dev. 64(5), 877-880 (2016). https://doi.org/10.1007/s11423-016-9480-3

30. Brown, M., Klein, C.: Whose data? which rights? whose power? A policy discourse analysis of student privacy policy documents. J. High. Educ. 91(7),1149-1178. (2020). https://doi. org/10.1080/00221546.2020.1770045

31. Romero, C., Ventura, S.: Educational data mining: A review of the state of the art. Syst. Man Cybernet. Part C App. Rev. IEEE Trans. on 40(6), 601-618 (2010). https://doi.org/10.1109/ TSMCC.2010.2053532

32. Micari, M., Pazos, P.: Beyond grades: improving college students' social-cognitive outcomes in STEM through a collaborative learning environment. Learn. Environ. Res. In press (2020). https://doi.org/10.1007/s10984-020-09325-y

33. Zhang, X., Meng, Y., Ordóñez de Pablos, P., Sun, Y.: Learning analytics in collaborative learning supported by slack: From the perspective of engagement. Comput. Hum. Behav. 92, 625-633 (2019). https://doi.org/10.1016/j.chb.2017.08.012

34. Moreira, F., Ferreira, M.J., Santos Pereira, C., Gomes, A.S., Collazos, C.A., Fonseca, D.: ECLECTIC as a learning ecosystem for higher education disruption. Univ. Access Inf. Soc. 18(3), 615-631 (2019). https://doi.org/10.1007/s10209-019-00682-x
35. García-Peñalvo, F.J., Seoane-Pardo, A.M.: An updated review of the concept of eLearning Tenth anniversary. Educ. Knowl. Soc. 16(1), 119-144 (2015). https://doi.org/10.14201/eks20 15161119144

36. Duin, A.H., Tham, J.: The current state of analytics: Implications for learning management system (LMS) use in writing pedagogy. Comput. Compos. 55, 102544 (2020). https://doi. org/10.1016/j.compcom.2020.102544

37. Torres-Toukoumidis, Á., Ramírez-Montoya, M.S., RomeroRodríguez, L.M.: Valoración y evaluación de los aprendizajes basados en juegos (GBL) en contextos e-learning. Educ. Knowl. Soc. 19(4), 109-128 (2018). https://doi.org/10.14201/ eks2018194109128

38. Rojas-López, A., Rincón-Flores, E.G., Mena, J.J., GarcíaPeñalvo, F.J., Ramírez-Montoya, M.S.: Engagement in the course of programming in higher education through the use of gamification. Univ. Access Inf. Soc. 18(3), 583-597 (2019). https://doi.org/10.1007/s10209-019-00680-z

39. Romero, C., Ventura, S.: Educational data mining and learning analytics: An updated survey. WIREs Data Min. Knowl. Discov. 10(3), e1355 (2020). https://doi.org/10.1002/widm.1355

40. Simonette, M., Spina, E.: Management process of big data in high education as sociotechnical system. In: Burgos, D. (ed.) Radical Solutions and Learning Analytics: Personalised Learning and Teaching Through Big Data, pp. 57-66. Lecture Notes in Educational Technology, Springer Singapore, Singapore (2020)

41. Solé-Beteta, X., Navarro, J., Vernet, D., Zaballos, A., TorresKompen, R., Fonseca, D., Briones, A.: Automatic tutoring system to support cross-disciplinary training in big data. J. Supercomput. (2020). https://doi.org/10.1007/s11227-020-03330-x

42. Donovan, M.S., Bransford, J.D. (eds.): How students learn: history, mathematics, and science in the classroom. The National Academies Press, Washington, DC, USA (2005)

43. Fonseca Escudero, D., Conde-González, M.Á., García-Peñalvo, F.J.: Improving the information society skills: Is knowledge accessible for all? Univ. Access Inf. Soc. 17(2), 229-245 (2018). https://doi.org/10.1007/s10209-017-0548-6

44. Bardach, L., Klassen, R.M.: Smart teachers, successful students? A systematic review of the literature on teachers' cognitive abilities and teacher effectiveness. Educ. Res. Rev. 30, 100312 (2020). https://doi.org/10.1016/j.edurev.2020.100312

45. Fidalgo-Blanco, Á., Sein-Echaluce, M.L., García-Peñalvo, F.J.: Knowledge spirals in higher education teaching innovation. International J. Knowl. Manag. 10(4), 16-37 (2014). https://doi. org/10.4018/ijkm.2014100102

46. Fidalgo-Blanco, Á., Sein-Echaluce, M.L., García-Peñalvo, F.J.: Epistemological and ontological spirals: From individual experience in educational innovation to the organisational knowledge in the university sector. Progr. Electron. Libr. Inf. Syst 49(3), 266-288 (2015). https://doi.org/10.1108/PROG-06-2014-0033

47. Romero, S., Aláez, M., Amo, D., Fonseca, D.: Systematic review of how engineering schools around the world are deploying the 2030 agenda. Sustainability 12(12), 5035 (2020). https://doi. org/10.3390/su12125035

48. UNESCO COVID-19 Impact on Education. https://bit.ly/2yJW4 yy. Accessed On Abril 8 (2020)

49. Viner, R.M., Russell, S.J., Croker, H., Packer, J., Ward, J., Stansfield, C., Mytton, O., Bonell, C., Booy, R.: School closure and management practices during coronavirus outbreaks including COVID-19: A rapid systematic review. Lancet Child Adolescent Health 4(5), 397-404 (2020). https://doi.org/10.1016/S2352 $-4642(20) 30095-X$

50. Fardoun, H., González-González, C.S., Collazos, C.A., Yousef, M.: Estudio exploratorio en Iberoamérica sobre procesos de enseñanza-aprendizaje y propuesta de evaluación en tiempos 
de pandemia. Educ. Knowl. Soc. 21, 17 (2020). https://doi. org/10.14201/eks.23437

51. Mogaji, E., Jain, V.: Impact of the pandemic on higher education in emerging countries: emerging opportunities. SSRN, Challenges and Research Agenda (2020) https://doi.org/10.2139/ ssrn.3622592

52. Van Lancker, W., Parolin, Z.: COVID-19, school closures, and child poverty: A social crisis in the making. Lancet Public Health 5(5), e243-e244 (2020). https://doi.org/10.1016/S2468 $-2667(20) 30084-0$

53. Beaunoyer, E., Dupéré, S., Guitton, M.J.: COVID-19 and digital inequalities: Reciprocal impacts and mitigation strategies. Comput. Hum. Behav. 111, 106424 (2020). https://doi.org/10.1016/j. chb.2020.106424

54. Azevedo JP, Hasan A, Goldemberg D, Iqbal SA, Geven K Simulating the Potential Impacts of COVID-19 School Closures on Schooling and Learning Outcomes: A Set of Global Estimates. Policy Research Working Papers. The World Bank, Washington, DC, USA. (2020) doi:https://doi.org/10.1596/1813-9450-9284

55. Hodges C, Moore S, Lockee B, Trust T, Bond A (2020) The difference between emergency remote teaching and online learning. Educause Review. https://bit.ly/3b0Nzx7

56. Daniel, S.J.: Education and the COVID-19 pandemic. Prospects (2020). https://doi.org/10.1007/s11125-020-09464-3

57. García-Peñalvo, F.J., Corell, A., Abella-García, V., Grande, M.: La evaluación online en la educación superior en tiempos de la COVID-19. Educ. Knowl. Soc. 21, 12 (2020). https://doi. org/10.14201/eks.23013

58. García-Peñalvo FJ, Corell A (2020) La COVID-19: ¿enzima de la transformación digital de la docencia o reflejo de una crisis metodológica y competencial en la educación superior? Campus Virtuales 9 (2)

59. García-Holgado A, García-Peñalvo FJ A metamodel proposal for developing learning ecosystems. In: Zaphiris P, Ioannou A (Eds.) Learning and Collaboration Technologies. Novel Learning Ecosystems. 4th International Conference, LCT 2017. Held as Part of HCI International 2017, Vancouver, BC, Canada, July 9-14, 2017. Proceedings, Part I. Lecture Notes in Computer Science, vol 10295. Springer International Publishing, Switzerland, pp 100-109. (2017) doi:https://doi.org/10.1007/978-3-319-58509 $-3 \_10$

60. García-Holgado, A., García-Peñalvo, F.J.: Validation of the learning ecosystem metamodel using transformation rules. Future Gener. Comput. Syst. 91, 300-310 (2019). https://doi. org/10.1016/j.future.2018.09.011

61. Casillas Martín, S., Cabezas González, M., García-Peñalvo, F.J.: Digital competence of early childhood education teachers: attitude, knowledge and use of ICT. Europ. J. Teacher Educ. 43(2), 210-223 (2020). https://doi.org/10.1080/02619768.2019.16813 93

62. García-Peñalvo, F.J.: Modelo de referencia para la enseñanza no presencial en universidades presenciales. Campus Virtuales 9(1), 41-56 (2020c)

63. Fonseca, D.: User experience and access using augmented and multimedia technologies: special issue of UXeLATE (2012) Workshop and HCI International conference (2013) special sessions. Univ. Access Inf. Soc. 14(3), 307-310 (2015). https://doi. org/10.1007/s10209-014-0360-5

64. Conde, M.Á., Fonseca, D.: Information society skills: Is knowledge accessible for all? Part I. Univ. Access Inf. Soc. 17(2), 223-227 (2018). https://doi.org/10.1007/s10209-017-0547-7

65. Fonseca, D., Conde, M.Á.: Information society skills: Is knowledge accessible for all? part II. Univ. Access Inf. Soc. 17(3), 447-451 (2018). https://doi.org/10.1007/s10209-017-0554-8

66. Fonseca, D., García-Peñalvo, F.J.: Interactive and collaborative technological ecosystems for improving academic motivation and engagement. Univ. Access Inf. Soc. 18(3), 423-430 (2019). https ://doi.org/10.1007/s10209-019-00669-8

67. Zaphiris P, Ioannou A (Eds.) Learning and Collaboration Technologies. Designing Learning Experiences. 6th International Conference, LCT 2019, Held as Part of the 21st HCI International Conference, HCII 2019, Orlando, FL, USA, July 26-31, 2019, Proceedings, Part I. Lecture Notes in Computer Science, vol LNCS 11590. Springer Nature, Cham, Switzerland. (2019) doi:https://doi.org/10.1007/978-3-030-21814-0

68. Zaphiris P, Ioannou A (Eds.) Learning and Collaboration Technologies. Designing Learning Experiences. 6th International Conference, LCT 2019, Held as Part of the 21st HCI International Conference, HCII 2019, Orlando, FL, USA, July 26-31, 2019, Proceedings, Part II. Lecture Notes in Computer Science, vol LNCS 11591. Springer Nature, Cham, Switzerland. (2019) doi:https://doi.org/10.1007/978-3-030-21817-1

69. Conde-González MÁ, Rodríguez-Sedano FJ, Fernández-Llamas C, García-Peñalvo FJ (Eds.) TEEM'19 Proceedings of the Seventh International Conference on Technological Ecosystems for Enhancing Multiculturality (Leon, Spain, October 16th-18th, 2019). ACM, New York, USA (2019)

70. Yu, Z.: Visualizing artificial intelligence used in education over two decades. J. Inf. Technol. Res. 13(4), 32-46 (2020)

71. Conde MÁ, Rodríguez Sedano FJ, Fernández-Llamas C, Gonçalves J, Lima J, García-Peñalvo FJ RoboSTEAM Project Systematic Mapping: Challenge Based Learning and Robotics. In: 2020 IEEE Global Engineering Education Conference (EDUCON), (27-30 April 2020, Porto, Portugal). IEEE, USA, pp 214-221 (2020) doi:https://doi.org/10.1109/EDUCON4565 0.2020 .9125103

72. Ferrada-Ferrada, C., Carrillo-Rosúa, J., Díaz-Levicoy, D., SilvaDíaz, F.: Robotics from STEM areas in primary school: A systematic review. Educ. Knowl. Soc. 21, 22 (2020). https://doi. org/10.14201/eks.22036

73. Jurado, E., Fonseca, D., Coderch, J., Canaleta, X.: Social steam learning at an early age with robotic platforms: A case study in four schools in Spain. Sensors 20(13), 3698 (2020). https://doi. org/10.3390/s20133698

74. Joo-Nagata, J., Martínez Abad, F., García-Bermejo Giner, J., García-Peñalvo, F.J.: Augmented reality and pedestrian navigation through its implementation in m-learning and e-learning: Evaluation of an educational program in Chile. Comput. Educ. 111, 1-17 (2017). https://doi.org/10.1016/j.compe du.2017.04.003

75. Camba JD, Contero M From reality to augmented reality: Rapid strategies for developing marker-based AR content using image capturing and authoring tools. In: Proceedings of the 2015 IEEE Frontiers in Education Conference (FIE) (El Paso, TX, USA, 21-24 Oct. 2015). IEEE, USA (2015) doi:https://doi. org/10.1109/FIE.2015.7344162

76. Fonseca, D., Martí, N., Redondo, E., Navarro, I., Sánchez, A.: Relationship between student profile, tool use, participation, and academic performance with the use of augmented reality technology for visualized architecture models. Comput. Hum. Behav. 31, 434-445 (2014). https://doi.org/10.1016/j.chb.2013.03.006

77. González-Izard, S., Sánchez Torres, R., Alonso Plaza, Ó., JuanesMéndez, J.A., García-Peñalvo, F.J.: Nextmed: automatic imaging segmentation, 3D reconstruction, and 3D model visualization platform using augmented and virtual reality. Sensors 20(10), 2962 (2020). https://doi.org/10.3390/s20102962

78. Mariscal, G., Jiménez, E., Vivas-Urias, M.D., Redondo-Duarte, S., Moreno-Pérez, S.: Virtual reality simulation-based learning. Educ. Knowl. Soc. 21, 11 (2020). https://doi.org/10.14201/ eks.20809

79. Camba JD, Soler JL, Contero M Immersive Visualization Technologies to Facilitate Multidisciplinary Design Education. 
In: Zaphiris P, Ioannou A (Eds.) Learning and Collaboration Technologies. Technology in Education. 4th International conference, LCT 2017. Held as Part of HCI International 2017, Vancouver, BC, Canada, July 9-14, 2017. Proceedings, Part I. Lecture Notes in Computer Science, vol 10295. Springer International Publishing, Switzerland, pp 3-11 (2017) doi:https://doi. org/10.1007/978-3-319-58509-3_1

80. Sanchez-Sepulveda, M.V., Torres-Kompen, R., Fonseca, D., Franquesa-Sanchez, J.: Methodologies of learning served by virtual reality: A case study in urban interventions. Appl. Sci. 9(23), 5161 (2019). https://doi.org/10.3390/app9235161

81. Sanchez-Sepulveda, M., Fonseca, D., Franquesa, J., Redondo, E.: Virtual interactive innovations applied for digital urban transformations. Mixed Approach Future Gener. Comput. Syst. 91, 371-381 (2019). https://doi.org/10.1016/j.future.2018.08.016

82. Villegas-Ch, W., Román-Cañizares, M., Palacios-Pacheco, X.: Improvement of an online education model with the integration of machine learning and data analysis in an LMS. Appl. Sci. 10(15), 5371 (2020). https://doi.org/10.3390/app10155371

83. Fiedler, S.H.D., Väljataga, T.: Modeling the personal adult learner: The concept of PLE re-interpreted. Interact. Learn. Environ. (In Press) (2020). https://doi.org/10.1080/10494 820.2020.1734027

84. Humanante-Ramos, P.R., García-Peñalvo, F.J., Conde-González, M.Á.: Personal learning environments and online classrooms: An experience with university students. IEEE RITA 10(1), 26-32 (2015). https://doi.org/10.1109/RITA.2015.2391411

85. Humanante-Ramos, P., García-Peñalvo, F.J., Conde-González, M.Á.: Entornos personales de aprendizaje móvil: Una revisión sistemática de la literatura. RIED Revista Iberoam. de Educación a Distancia 20(2), 73-92 (2017). https://doi.org/10.5944/ ried.20.2.17692

86. Tomé-Fernández, M., Curiel-Marín, E., Caraballo, E.: Use of mobile technologies in personal learning environments of intercultural contexts: Individual and group tasks. Electronics 9(5), 876 (2020). https://doi.org/10.3390/electronics9050876

87. Min, W., Frankosky, M.H., Mott, B.W., Rowe, J.P., Smith, A., Wiebe, E., Boyer, K.E., Lester, J.C.: Deepstealth: Game-based learning stealth assessment with deep neural networks. IEEE Trans. Learn. Technol. 13(2), 312-325 (2020). https://doi. org/10.1109/TLT.2019.2922356

88. Conde-González, M.Á., Colomo-Palacios, R., García-Peñalvo, F.J., Larrueca, X.: Teamwork assessment in the educational web of data: A learning analytics approach towards ISO 10018. Telemat. Inform. 35(3), 551-563 (2018). https://doi.org/10.1016/j. tele.2017.02.001

89. Bond, M., Buntins, K., Bedenlier, S., Zawacki-Richter, O., Kerres, M.: Mapping research in student engagement and educational technology in higher education: a systematic evidence map. International J. Educ. Technol. High. Educ. 17(1), 2 (2020). https://doi.org/10.1186/s41239-019-0176-8

90. Bond, M.: Facilitating student engagement through the flipped learning approach in K-12: A systematic review. Comput. Educ. 151, 103819 (2020). https://doi.org/10.1016/j.compe du.2020.103819

91. García-Holgado, A., García-Peñalvo, F.J., Butler, P.: Technological ecosystems in citizen science: A framework to involve children and young people. Sustainability 12(5), 1863 (2020). https://doi.org/10.3390/su12051863

92. Company, P., Contero, M., Otey, J., Camba, J.D., Agost, M.-J., Pérez-López, D.: Web-based system for adaptable rubrics: Case study on cad assessment. Educ. Technol. Soc. 20(3), 24-41 (2017)

93. Mora A, Riera D, Gonzalez C, Arnedo-Moreno J A Literature Review of Gamification Design Frameworks. In: Proceedings of the 2015 7th International Conference on Games and Virtual
Worlds for Serious Applications (VS-Games) (Skovde, Sweden, 16-18 Sept. 2015). IEEE, USA. (2015)doi:https://doi. org/10.1109/VS-GAMES.2015.7295760

94. Leclercq, T., Poncin, I., Hammedi, W.: Opening the black box of gameful experience: Implications for gamification process design. J. Retail. Consum. Serv. 52, 101882 (2020). https://doi. org/10.1016/j.jretconser.2019.07.007

95. L. S-DJ, D. CJ, M. C, M. A Immersive Visualization Technologies to Facilitate Multidisciplinary Design Education. In: Lackey S, Chen J (Eds.) Virtual, Augmented and Mixed Reality. 9th International Conference, VAMR 2017, Held as Part of HCI International 2017, Vancouver, BC, Canada, July 9-14, 2017, Proceedings. Lecture Notes in Computer Science, vol 10280. Springer International Publishing, Cham, Switzerland, pp 369-380. (2017) doi:https://doi.org/10.1007/978-3-31957987-0_30

96. Villegas, E., Labrador, E., Fonseca, D., Fernández-Guinea, S.: Methodology I'M IN applied to workshop: Successful educational practice for consultants in user experience with gamification fields. Univ. Access Inf. Soc. 18(3), 507-521 (2019). https://doi.org/10.1007/s10209-019-00675-w

97. Neset, T.-S., Andersson, L., Uhrqvist, O., Navarra, C.: Serious gaming for climate adaptation assessing the potential and challenges of a digital serious game for urban climate adaptation. Sustainability 12(5), 1789 (2020). https://doi.org/10.3390/ su12051789

98. Gauthier, A., Jenkinson, J.: Designing productively negative experiences with serious game mechanics: Qualitative analysis of game-play and game design in a randomized trial. Comput. Educ. 127, 66-89 (2018). https://doi.org/10.1016/j.compe du.2018.08.017

99. Arjoranta, J., Kari, T., Salo, M.: Exploring features of the pervasive game pokémon go that enable behavior change: qualitative study. JMIR Serious Games 8(2), e15967 (2020). https:// doi.org/10.2196/15967

100. González-González, C.S.: State of the art in the teaching of computational thinking and programming in childhood education. Educ. Knowl. Soc. 20, 17 (2019). https://doi.org/10.14201 /eks2019_20_a17

101. Chang, C.-S., Chung, C.-H., Chang, J.A.: Influence of problem-based learning games on effective computer programming learning in higher education. Educ. Technol. Res. Develop. In press (2020). https://doi.org/10.1007/s11423-020-09784-3

102. Valls, F., Redondo, E., Fonseca, D., Torres-Kompen, R., Villagrasa, S., Martí, N.: Urban data and urban design: A data mining approach to architecture education. Telemat. Inf. 35(4), 1039-1052 (2018). https://doi.org/10.1016/j.tele.2017.09.015

103. Knight, S., Gibson, A., Shibani, A.: Implementing learning analytics for learning impact: Taking tools to task. Internet High. Educ. 45, 100729 (2020). https://doi.org/10.1016/j.ihedu c. 2020.100729

104. Chi, L.-P., Zhuang, Z.-Y., Fu, C.-H., Huang, J.-H.: A knowledge discovery education framework targeting the effective budget use and opinion explorations in designing specific high cost product. Sustainability 10(8), 2742 (2018). https:// doi.org/10.3390/su10082742

105. Chen, T., Peng, L., Yin, X., Rong, J., Yang, J., Cong, G.: Analysis of user satisfaction with online education platforms in china during the COVID-19 pandemic. Healthcare 8(3), 200 (2020). https://doi.org/10.3390/healthcare 8030200

106. García-Peñalvo, F.J., Vázquez-Ingelmo, A., García-Holgado, A., Seoane-Pardo, A.M.: Analyzing the usability of the WYRED platform with undergraduate students to improve its features. Univ. Access Inf. Soc. 18(3), 455-468 (2019). https ://doi.org/10.1007/s10209-019-00672-z 
107. Wentzel, K.R., Jablansky, S., Scalise, N.R.: Peer social acceptance and academic achievement: A meta-analytic study. J. Educ. Psychol. In Press (2020). https://doi.org/10.1037/edu0000468

108. Gómez-Aguilar, D.A., Therón, R., García-Peñalvo, F.J.: Semantic spiral timelines used as support for e-learning. J. Univ. Comput. Sci. 15(7), 1526-1545 (2009). https://doi.org/10.3217/ jucs-015-07-1526

109. Baker CM, El-Glaly YN, Shinohara K A Systematic Analysis of Accessibility in Computing Education Research. In: SIGCSE'20: Proceedings of the 51st ACM Technical Symposium on Computer Science Education (Portland, OR, USA, March, 2020). ACM, New York, NY, USA, pp 107-113 (2020) doi:https://doi. org/10.1145/3328778.3366843

110. Hu, L., He, S., Luo, Y., Su, S., Xin, J., Weng, M.: A social-mediabased approach to assessing the effectiveness of equitable housing policy in mitigating education accessibility induced social inequalities in Shanghai. China. Land Use Policy 94, 104513 (2020). https://doi.org/10.1016/j.landusepol.2020.104513

111. González Izard, S., Juanes-Méndez, J.A., Ruisoto Palomera, P.: Virtual reality educational tool for human anatomy. J. Med. Syst. 41(5), 76 (2017). https://doi.org/10.1007/s10916-017-0723-6

112. Fonseca Escudero, D., Redondo Domínguez, E., Valls, F.: Motivation and academic improvement using augmented reality for 3D architectural visualization. Educ. Knowl. Soc. 17(1), 45-64 (2016)

113. Sanchez-Sepulveda, M.V., Fonseca, D., García-Holgado, A., García-Peñalvo, F.J., Frabquesa, J., Redondo, E., Moreira, F.: Evaluation of an interactive educational system in urban knowledge acquisition and representation based on students' profiles. Expert Syst. In Press (2020). https://doi.org/10.1111/exsy.12570

114. Balderas, A., Berns, A., Palomo-Duarte, M., Dodero, J.M., RuizRube, I.: Retrieving objective indicators from student logs in virtual worlds. J. Inform. Technol. Res. 10(3), 69-83 (2017)

115. Crisol-Moya, E., Herrera-Nieves, L., Montes-Soldado, R.: Educación virtual para todos: Una revisión sistemática. Educ. Knowl. Soc. 21, 15 (2020). https://doi.org/10.14201/eks.20327
116. Montola, M., Stenros, J., Waern, A.: Pervasive games: Theory and design. Morgan Kaufmann Publishers Inc., San Francisco, USA (2009)

117. García-Peñalvo, F.J., Mendes, J.A.: Exploring the computational thinking effects in pre-university education. Comput. Hum. Behav. 80, 407-411 (2018). https://doi.org/10.1016/j. chb.2017.12.005

118. Zapata-Ros, M.: Computational thinking unplugged. Educ. Knowl. Soc. 20, 18 (2019). https://doi.org/10.14201/eks20 19_20_a18

119. Kitchenham B, Charters S Guidelines for performing Systematic Literature Reviews in Software Engineering. Version 2.3 School of Computer Science and Mathematics, Keele University (2007)

120. Pagano, A., Palombini, A., Bozzelli, G., Nino, M., Cerato, I., Ricciardi, S.: Arkaevision vr game: User experience research between real and virtual paestum. Appl. Sci. 10(9), 3182 (2020). https://doi.org/10.3390/app10093182

121. Elmunsyah, H., Hidayat, W.N., Ulfa, S., Surakhman, E., Wakhidah, R.: Measuring user experience on personalized online training system to support online learning. IOP Conference Series: Materials Science and Engineering 732, 012115 (2020). https:// doi.org/10.1088/1757-899X/732/1/012115

122. Colomo-Palacios, R., García-Peñalvo, F.J., Stantchev, V., Misra, S.: Towards a social and context-aware mobile recommendation system for tourism. Pervasive Mob. Comput. 38, 505-515 (2017). https://doi.org/10.1016/j.pmcj.2016.03.001

123. Navarrete, R., Luján-Mora, S.: Bridging the accessibility gap in Open Educational Resources. Univ. Access Inf. Soc. 17(4), 755-774 (2018). https://doi.org/10.1007/s10209-017-0529-9

Publisher's Note Springer Nature remains neutral with regard to jurisdictional claims in published maps and institutional affiliations. 